\title{
Effect of ArtinM on Human Blood Cells During Infection With Paracoccidioides brasiliensis
}

\section{Luciana P. Ruas ${ }^{1}$, Livia M. Genaro', Amauri S. Justo-Junior'1, Lilian O. Coser'1, Livia F. de Castro ${ }^{1}$, Plinio Trabasso', Ronei L. Mamoni ${ }^{1,3}$, Maria-Cristina Roque-Barreira ${ }^{4}$ and Maria-Heloisa S. L. Blotta ${ }^{1 *}$}

\begin{abstract}
'Department of Clinical Pathology, School of Medical Sciences, State University of Campinas (UNICAMP), Campinas, Brazil, ${ }^{2}$ Department of Internal Medicine, School of Medical Sciences, State University of Campinas (UNICAMP), Campinas, Brazil, ${ }^{3}$ Department of Morphology and Basic Pathology, Faculty of Medicine of Jundiaí, Jundiaí, Brazil, ${ }^{4}$ Department of Cell and Molecular Biology, Medical School of Ribeirão Preto, University of São Paulo, Ribeirão Preto, Brazil
\end{abstract}

Infections caused by fungi are prominent in our environment and can be potentially fatal. paracoccidioidomycosis (PCM), caused by fungi of the Paracoccidioides genus, is the most frequent systemic mycosis in Brazil and the main cause of death among immunocompetent individuals. The antifungal therapy for PCM is usually effective but side effects and relapses are often reported. The latter could be avoided with alternative or complementary therapies aimed at boosting the immune response to combat this pathogen. Recent reports have pointed at the importance of an effective cellular immune response, with the participation of Th1 cells, in the resistance to and control of Paracoccidioides infection. The ArtinM lectin, extracted from jackfruit (Artocarpus heterophyllus) seeds, exhibits immunomodulatory activity against several intracellular pathogens, including Paracoccidioides brasiliensis, by promoting the development of a Th1 immune response. The aim of this work was to characterize the effect of ArtinM on peripheral blood cells of patients with PCM and on those of control individuals infected with fungal yeasts cells in vitro. Our results demonstrate that ArtinM activates human neutrophils in vitro, leading to an increase in cytokine production and CD54 expression. ArtinM activated $P$. brasiliensis-infected neutrophils from both healthy individuals and patients with PCM. This activation was not dependent on the dectin-1 receptor, because pre-incubation with laminarin, a dectin-1 receptor blocker, did not reverse the activated state of the cells. ArtinM also stimulated human peripheral blood mononuclear cells to secrete pro-inflammatory Th1-related cytokines, which are protective against Paracoccidioides infection. These data support the immunostimulatory action of ArtinM and encourage new studies using the lectin for the immunotherapy of PCM.

\footnotetext{
Keywords: Paracoccidioides, paracoccidioidomycosis, ArtinM, fungal infection, immune modulation, lectin, neutrophils
}

\section{INTRODUCTION}

Paracoccidioidomycosis (PCM) is a systemic mycosis that affects tropical and subtropical regions of Latin America. In addition to Brazil, where most cases are reported, Argentina, Venezuela, Colombia, and Ecuador also have a high incidence of PCM (Brummer et al., 1993; Marques, 2003; Restrepo et al., 2012). The disease can affect both children and adults, and is caused by 
dimorphic fungi of the Paracoccidioides genus, such as Paracoccidioides brasiliensis, which is the best studied species (Teixeira et al., 2009; Teixeira Mde et al., 2014). The disease can be localized or disseminated, involving mainly the lungs, skin, mucosa, lymph nodes, and central nervous system (Borges-Walmsley et al., 2002).

Paracoccidioidomycosis represents an important public health problem because of its high incapacitating ability and the high premature mortality it causes, especially in rural populations, where PCM is a major cause of death among immunocompetent individuals (Bagagli et al., 2006; Marques, 2012). PCM is characterized by a suppression of the cellular immune response in susceptible individuals, and by the formation of loose and compact granulomas in susceptible and resistant mice, respectively (Calich et al., 1998). Several studies, both in mice and humans, have shown that an efficient immune response against $P$. brasiliensis requires the activation of macrophages and Th1 lymphocytes (Benard et al., 1997, 2001; Calich and Kashino, 1998; Oliveira et al., 2002; Mamoni and Blotta, 2006; Calich et al., 2008).

Although antifungal therapy is being used with success in mycosis caused by dimorphic fungi, the toxicity associated to the therapy constitutes a problem (Bates et al., 2001; Nett and Andes, 2016). For instance, due to its low cost, sulfamethoxazole/trimethoprim is the most common choice for the treatment of PCM in low-income countries, and these, coincidentally, are the major endemic areas. Although this combination is synergistic against the fungus, it has the potential for myelotoxicity, since the drugs sequentially inhibit folate synthesis (Bellmann and Smuszkiewicz, 2017). Itraconazole, a triazole derivate, exhibits the potential for hepatotoxicity, and this might be an issue when treating patients with alcoholism, a very common comorbidity among PCM patients. Furthermore, at least in Brazil, itraconazole is marketed only as tablets with poor or erratic absorption by the gastrointestinal tract (Bellmann and Smuszkiewicz, 2017). Lastly, amphotericin B, a polyene antifungal drug occasionally used for treating life-threatening clinical manifestations of PCM, is well known to be associated with nephrotoxicity, particularly with the use of the deoxycholate formulation (Bellmann and Smuszkiewicz, 2017). In addition, PCM requires a prolonged treatment, usually of more than 1 year, and $20 \%$ of the patients present with sequelae, relapse, or complications of the disease (Martinez, 2010). Therefore, more research is needed to develop adjuvant therapies that decrease treatment length and toxicity. One such strategy could be the use of immunotherapies to boost the host immune response to overcome the fungus (Romani, 2011; Ruas et al., 2012; Kullberg et al., 2014).

Lectins are sugar-binding proteins found in virtually all organisms, from viruses to humans (Sharon, 2008). They are involved in several biological activities including adhesion of pathogens to host cells, induction of leukocyte activation and migration, and induction of cytokine production (Sharon and Lis, 2004). Plant lectins have been investigated for decades in biomedical research and are the best studied lectins (Souza et al., 2013). Several plant lectins are considered immunomodulatory agents with high biotechnological potential (Reis et al., 2008; Afonso-Cardoso et al., 2011; de Oliveira et al., 2013; Poiroux et al., 2017). The functionality of these molecules derives from their interaction with glycosylated receptors on the cell surface, which triggers intracellular signaling cascades that culminate in a range of biological responses, including production of cytokines, resulting in an efficient immune response against tumors and microbes (da Silva Correia and Ulevitch, 2002; Unitt and Hornigold, 2011).

ArtinM, obtained from the seeds of Artocarpus heterophyllus, is a D-mannose binding lectin with immunomodulatory properties (Souza et al., 2013). ArtinM interacts with TLR2 on macrophages and dendritic cells, resulting in IL-12 production and a polarization of the immune response to a Th1-type (Mariano et al., 2014). Indeed, ArtinM administration to mice leads to protection against several intracellular pathogens, including Leishmania major (Panunto-Castelo et al., 2001), Leishmania amazonensis (Teixeira et al., 2006), P. brasiliensis (Coltri et al., 2008, 2010), Neospora caninum (Cardoso et al., 2011), and Candida albicans (Loyola et al., 2012). Specifically, $P$. brasiliensis-experimentally infected mice that received ArtinM, either as a prophylactic or therapeutic regimen, had reduced fungal loads in organs and an increased production of immune mediators, such as IL-12 and TNF- $\alpha$ which resulted in protection of mice against the infection (Coltri et al., 2008, 2010). In addition, ArtinM has been reported to have an effect on human cells such as mast cells and neutrophils (Moreno et al., 2003; Pereira-da-Silva et al., 2006; Toledo et al., 2009; Barbosa-Lorenzi et al., 2011, 2016); however, these studies did not include any pathogens or diseases. Therefore, our aim was to evaluate the potential immunostimulatory effect of the lectin ArtinM on cells from PCM patients.

\section{MATERIALS AND METHODS}

\section{Donors}

Peripheral venous blood was collected from healthy individuals and from PCM patients who attended the University Clinical Hospital of UNICAMP, Campinas, Sao Paulo, Brazil. The diagnosis of PCM was established by identifying the fungus through direct examination, biopsy, or both. The study only included PCM patients with active disease before treatment started or within the first month of treatment. For some assays, blood cells (peripheral blood mononuclear cells - PBMCs or neutrophils) from healthy individuals (controls) were infected with $P$. brasiliensis viable yeasts in vitro. Participants were informed about the study and voluntarily signed an informed consent form, as established by the Brazilian National Research Ethics Committee CEP/CONEP (\# 574 507).

\section{Fungi}

The highly virulent $\mathrm{Pb} 18$ isolate was used throughout the study, as previously described (Kashino et al., 1985). Yeast cells maintained in Fava-Netto medium at $37^{\circ} \mathrm{C}$ were subcultured weekly and used after 5 days of culture. To maintain the virulence, consecutive passages in mice were carried out by intravenous infection followed by recovery of the fungal isolate from mice tissues. Cells were suspended in phosphate-buffered 
saline (PBS $\mathrm{pH}$ 7.2) and homogenized with glass beads in a Vortex homogenizer to obtain individual cells. Yeast viability was determined by the trypan blue exclusion test and only suspensions with more than $85 \%$ of viable cells were used. The opsonization of $P$. brasiliensis yeast cells was carried out by incubating the cells with serum from PCM patients for $10 \mathrm{~min}$ at room temperature. The concentration of yeast cells used in each set of experiments was determined as needed.

\section{ArtinM Preparations}

ArtinM lectin was isolated from A. heterophyllus seeds and purified by sugar affinity chromatography as previously described (Santos-de-Oliveira et al., 1994).

\section{Isolation of PBMCs and Polymorphonuclear Cells (PMNs)}

Peripheral blood of PCM patients and healthy controls was collected in tubes containing sodium heparin. PBMCs were isolated using Ficoll-Hypaque ${ }^{\circledR}$ (GE Healthcare, United Kingdom) density gradient centrifugation. The buffy coat containing PMNs was transferred to a $15-\mathrm{mL}$ falcon tube, resuspended in red-cell lysis buffer, and incubated at room temperature for $10 \mathrm{~min}$. After washing, the number and viability of PBMCs and neutrophils were estimated by trypan blue exclusion. Cells were plated in 24-well plates with RPMI (Gibco/Thermo Fisher Scientific, Waltham, MA, United States) supplemented with $10 \%$ inactivated fetal calf serum, $100 \mathrm{U} / \mathrm{mL}$ gentamicin, $2 \mathrm{mM}$ L-glutamine, and $1 \mathrm{mM}$ sodium pyruvate (all from Sigma-Aldrich, St Louis, MO, United States). Cells were incubated with different stimuli for different times as described below.

\section{Blood Cell Stimulation}

Freshly isolated neutrophils and PBMCs were stimulated with ArtinM $(2.5$ or $5 \mu \mathrm{g} / \mathrm{mL}$ ), as previously described (Toledo et al., 2009; Ricci-Azevedo et al., 2016). PMA (50 ng/mL), LPS $(1 \mu \mathrm{g} / \mathrm{mL})$, and PHA $(10 \mu \mathrm{g} / \mathrm{mL})$ were used as positive controls. For some assays, neutrophils were pre-incubated for $30 \mathrm{~min}$ with $1 \mathrm{mg} / \mathrm{mL}$ of laminarin $(\beta-[1 \rightarrow 3]$-glucan soluble polymer, obtained from Laminaria digitata, Invitrogen, San Diego, CA, United States) to block the dectin-1 receptor (Brown et al., 2002). For the in vitro infection assays, cells were incubated with $P$. brasiliensis yeasts (yeast:neutrophil ratio of 1:10) in the presence or absence of ArtinM.

Cells were maintained at $37^{\circ} \mathrm{C}$ for $4-18 \mathrm{~h}$ (neutrophils) or 24-48 h (PBMCs), followed by collection of the supernatants for cytokine determination by ELISA according to the manufacturer's instructions (R\&D Systems, Minneapolis, MN, United States). In addition, neutrophil pellets were collected for the analysis of CD54 expression by FACS.

\section{Purification of CD14+ Cells and Differentiation Into Macrophages}

After PBMC isolation, $\mathrm{CD} 14^{+}$cells were purified using positive isolation kits, according to the manufacturer's instructions (MACs; Miltenyi Biotec, Germany). The purity of cell separation was evaluated by flow cytometry ( $>95 \%$ purity). Macrophages were differentiated from the $\mathrm{CD}_{14}{ }^{+}$cells with GM-CSF (50 ng/mL; Biolegend, San Diego, CA, United States) for 5 days and maintained at $37^{\circ} \mathrm{C}\left(5 \% \mathrm{CO}_{2}\right)$ in RPMI 1640 supplemented medium. After 7 days, macrophage differentiation was confirmed by microscopy and by the expression of markers as determined by flow cytometry (data not shown).

\section{Phagocytosis Assays}

Paracoccidioides brasiliensis yeast cells were labeled with CFSE (1 $\mu \mathrm{M}$, Sigma-Aldrich) for $5 \mathrm{~min}$. Neutrophils and macrophages were stimulated with ArtinM $(2.5 \mu \mathrm{g} / \mathrm{mL})$ and CFSE- $P$. brasiliensis yeast cells (ratio of 1:5) for $4 \mathrm{~h}$. As a positive control, we used FITC-conjugated Dextran-40 (1 mg/mL, Sigma-Aldrich). The cells were fixed with $2 \%$ formaldehyde and analyzed by flow cytometry.

For the killing assays, $P$. brasiliensis yeast cells were incubated with neutrophils or macrophages (ratio of $1: 50$ ) for $24 \mathrm{~h}$ at $37^{\circ} \mathrm{C}$ $\left(5 \% \mathrm{CO}_{2}\right)$. After incubation, neutrophils and macrophages were collected and washed with sterile distilled water to promote cell lysis. The suspension $(100 \mu \mathrm{L})$ was spread on BHI agar plates supplemented with $4 \%$ normal horse serum, 5\% P. brasiliensis growth factor, and $0.5 \%$ gentamicin. A control culture, containing only $P$. brasiliensis yeast cells, underwent the same procedures as the experimental cultures. The number of colony forming units (CFUs) was determined on the 7 th and 15th days of culture, and the percentage of killing (fungicidal capacity of cells) was calculated using the formula:

$$
\% \text { killing }=\left[1-\frac{\text { CFU number in experimental plates }}{\text { CFU number in control plates }}\right] \times 100
$$

\section{Flow Cytometry}

Cell pellets (approximately $5 \times 10^{5}$ cells) of neutrophils cultured in the presence of ArtinM were incubated for $20 \mathrm{~min}$ at $4^{\circ} \mathrm{C}$ with anti-CD54-PE and anti-CD16-APC antibodies (Biolegend), washed, and fixed with $2 \%$ formaldehyde. Labeled and fixed cells were kept in the refrigerator and protected from light, until signal acquisition was performed using a BD-FACSCalibur ${ }^{\circledR}$ or FACSVerse ${ }^{\circledR}$ flow cytometer (BD Biosciences, San Jose, CA, United States). Analysis of the dotplot or mean fluorescence intensity (MFI) was performed using the FCS Express program (De Novo Software, Glendale, CA, United States).

\section{Statistical Analysis}

Statistical analysis was performed using GraphPad InStat ${ }^{\circledR}$ version 6 (GraphPad Software, San Diego, CA, United States). Normality of data was assessed using the KolmogorovSmirnov test. Differences between the averages of the various stimuli were assessed by ANOVA for repeated measures followed by Tukey's post hoc test. For comparisons of the same parameter between different groups, the $t$-test was used. $P$ values of less than 0.05 were considered statistical significant. 


\section{RESULTS}

\section{ArtinM Activates Human Neutrophils Stimulated With $P$. brasiliensis Yeast Cells in Vitro}

Neutrophils from healthy individuals were stimulated in vitro with $P$. brasiliensis yeast cells, ArtinM, or both, for different times, and cytokine production in supernatants was determined as outlined in Section "Materials and Methods." An increased TNF- $\alpha$ production was observed in neutrophils infected with P. brasiliensis after $18 \mathrm{~h}$ of incubation with ArtinM (Figure 1A), while induction of TNF- $\alpha$ production in uninfected neutrophils occurred much earlier (4 h).

Previous reports had shown that ArtinM stimulation leads to IL-8 production in human neutrophils (Toledo et al., 2009; Ricci-Azevedo et al., 2016). Here, we evaluated whether this also occurs during PCM. Our results showed that ArtinM induces an early IL-8 production in neutrophils infected with P. brasiliensis (Figure 1B). After $18 \mathrm{~h}$, the production of IL- 8 induced by ArtinM reached similar levels to those induced by PMA stimulation, even in the presence of $P$. brasiliensis.

Because ArtinM stimulation of neutrophils led to the production of pro-inflammatory cytokines, we quantified IL-1 $\beta$ production in neutrophils infected in vitro with $P$. brasiliensis. We found that ArtinM induced IL- $\beta$ production in both infected and uninfected neutrophils. After $18 \mathrm{~h}$, we found that even the lowest concentration of lectin $(2.5 \mu \mathrm{g} / \mathrm{mL})$ led to the production of IL-1 $\beta$ in cells infected with $P$. brasiliensis (Figure 1C).

Next, we evaluated whether activation of these cells was also reflected by expression of CD54/ICAM-1, a molecule involved in neutrophil adhesion and activation. ArtinM induced a ninefold increase in CD54/ICAM-1 expression on neutrophils (Figure 1D). The addition of $2.5 \mu \mathrm{g} / \mathrm{mL}$ of the lectin to neutrophils doubled the percentage of $\mathrm{CD} 54^{+}$neutrophils, even in cells infected with viable yeasts (Figure 1E).

\section{ArtinM Activates Neutrophils From PCM Patients}

Next, we assessed if the beneficial effects promoted by ArtinM during in vitro fungal infection were reproduced in individuals with PCM. To this end, blood from patients with active disease was collected. As shown in Figure 2, ArtinM stimulated the production of TNF- $\alpha$ and IL- 8 in neutrophils of PCM patients after $18 \mathrm{~h}$ of incubation. Importantly, even though the basal levels of IL- 8 produced by neutrophils of PCM patients were already high, ArtinM was still able to stimulate these neutrophils, leading to a sevenfold rise in IL- 8 production compared to unstimulated cells (Figure 2B). In addition, ArtinM enhanced TNF- $\alpha$ production in neutrophils of PCM patients leading to a 6and 100 -fold increase after 4 and $18 \mathrm{~h}$ of incubation, respectively (Figure 2A). Moreover, IL-1 $\beta$ production was also induced in neutrophils of PCM patients after $18 \mathrm{~h}$ of incubation with ArtinM compared to unstimulated cells, although this difference was not statistically significant (Figure 2C).

Finally, we evaluated the effect of ArtinM stimulation on the frequency and expression of the CD54 molecule in neutrophils of PCM patients. Similar to that observed in cells from healthy individuals infected in vitro, an increase in the expression of CD54 on neutrophils from PCM patients was observed following ArtinM stimulation (Figure 2D). Almost 100\% of these neutrophils were already $\mathrm{CD}_{54}{ }^{+}$; therefore, an increase in this population could not be detected after the addition of the lectin (Figure 2E).

\section{Neutrophil Activation by ArtinM Is Independent of $\beta$-Glucan Receptor Dectin-1}

Dectin-1 is involved in the production of TNF- $\alpha$ by cells in response to fungal recognition (Brown et al., 2003). Therefore, we evaluated if dectin-1 was also involved in cell activation in response to ArtinM. To this end, cells were pre-treated with the dectin-1 antagonist laminarin for $30 \mathrm{~min}$, followed by incubation with ArtinM, and measurement of activation parameters as before. Pre-incubation of neutrophils from healthy individuals with laminarin did not affect TNF- $\alpha$ production in response to ArtinM (Figure 3), neither was affected the percentage of CD54 ${ }^{+}$ cells or CD54 expression in neutrophils infected in vitro with $P$. brasiliensis or in neutrophils from PCM patients (data not shown). These data suggest that activation of infected neutrophils by ArtinM does not depend on the receptor dectin-1.

\section{ArtinM Activates PBMCs Stimulated in Vitro With $P$. brasiliensis Yeast Cells}

Next, we wanted to assay the effect of the ArtinM lectin on other blood cell types. To this end, we used PBMCs from healthy individuals infected in vitro with $P$. brasiliensis yeasts. ArtinM induced an increased production of the Th1 cytokines IFN$\gamma$ (Figure 4A), MIG/CXCL9 (Figure 4B), and IP10/CXCL10 (Figure 4C) in PBMCs of healthy individuals regardless of whether they had been infected with $P$. brasiliensis yeasts. The increase in cytokine production was detected for the two lectin concentrations tested (2.5 and $5 \mu \mathrm{g} / \mathrm{mL})$. MIG and IP10 chemokines are related to the Th1-type immune response, because they are induced by IFN- $\gamma$ (Luster et al., 1985; Farber, 1990). Polarization to a Th1 response has already been suggested to be the mechanism of action of ArtinM against several pathogens in experimental models (Panunto-Castelo et al., 2001; Teixeira et al., 2006; Coltri et al., 2008, 2010; Cardoso et al., 2011; Custodio et al., 2011).

\section{ArtinM Activates PBMC From PCM Patients}

To evaluate the effect of ArtinM during human PCM, venous blood from PCM patients was collected and PBMCs were stimulated with ArtinM for 24 and $48 \mathrm{~h}$. Cytokine production was quantified in the supernatants as described in the Materials and Methods section. Consistent with the results from in vitro infection of healthy PBMCs, ArtinM stimulation of cells from PCM patients induced an increased production of IFN- $\gamma$ (Figure 5A), MIG (Figure 5B), and IP-10 (Figure 5C). Our results confirm that the Th1 polarization induced by ArtinM 


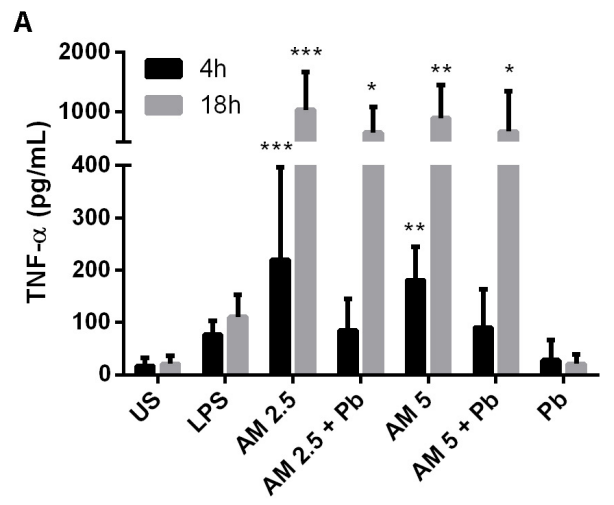

C

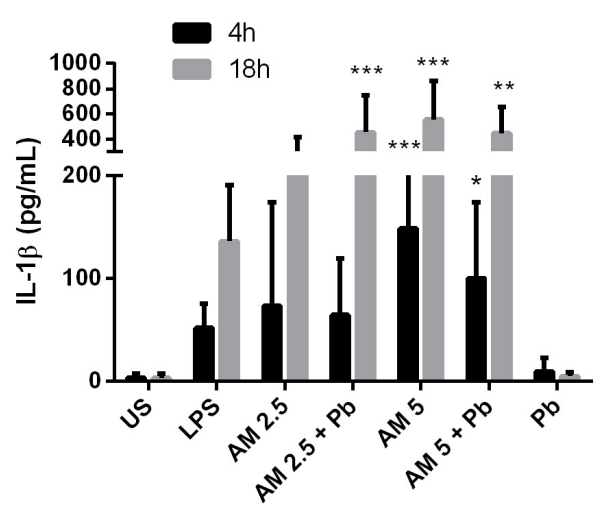

E

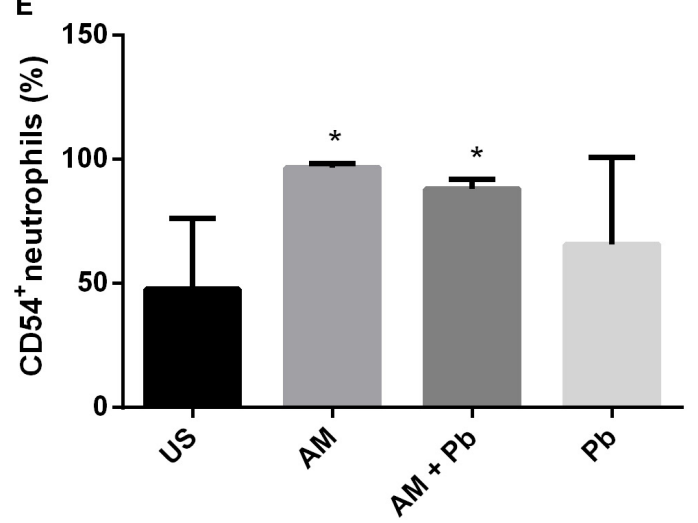

B

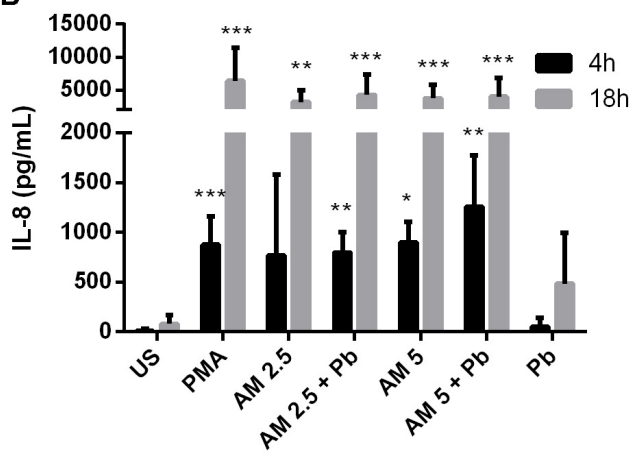

D

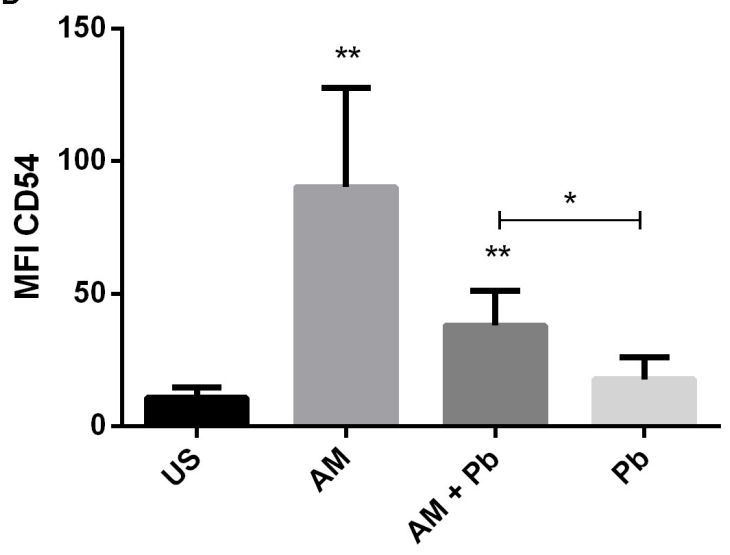

FIGURE 1 | ArtinM induces activation and cytokine production in neutrophils infected with $P$. brasiliensis yeast cells in vitro. Neutrophils obtained from the peripheral blood of healthy individuals $(n=10)$ were maintained in vitro in the presence of the indicated stimuli, for 4 and 18 h. Culture supernatants were collected and used for cytokine quantification by ELISA (A: TNF- $\alpha$, B: IL-8, C: IL-1 $\beta$ ). Cell pellets were assayed for CD54 expression (D) and frequency (E) by FACs. AM: ArtinM, $\mathrm{Pb}$ : $P$. brasiliensis yeast (yeast:neutrophil ratio of $1: 10$ ), US: unstimulated. ${ }^{*} P \leq 0.05,{ }^{* *} P \leq 0.01,{ }^{* * *} P \leq 0.001$ compared to US.

during experimental PCM also occurs in human blood cells from PCM patients.

\section{ArtinM Promotes Increased $P$. brasiliensis Internalization by Neutrophils and Macrophages}

We next evaluated whether the activation of cells promoted by ArtinM would improve the phagocytic capacity of neutrophils and macrophages. We incubated CFSE-labeled $\mathrm{Pb}$ yeast with cells, with or without ArtinM, and used FITC-dextran as a positive control. As shown in Figure 6, ArtinM promoted the internalization of CFSE yeasts cells by both neutrophils and macrophages (Figures 6A,B). In macrophages, yeast opsonization was necessary to promote the internalization (Figure 6B). Since almost $100 \%$ of the neutrophils and macrophages internalized labeled dextran particles, we examined 

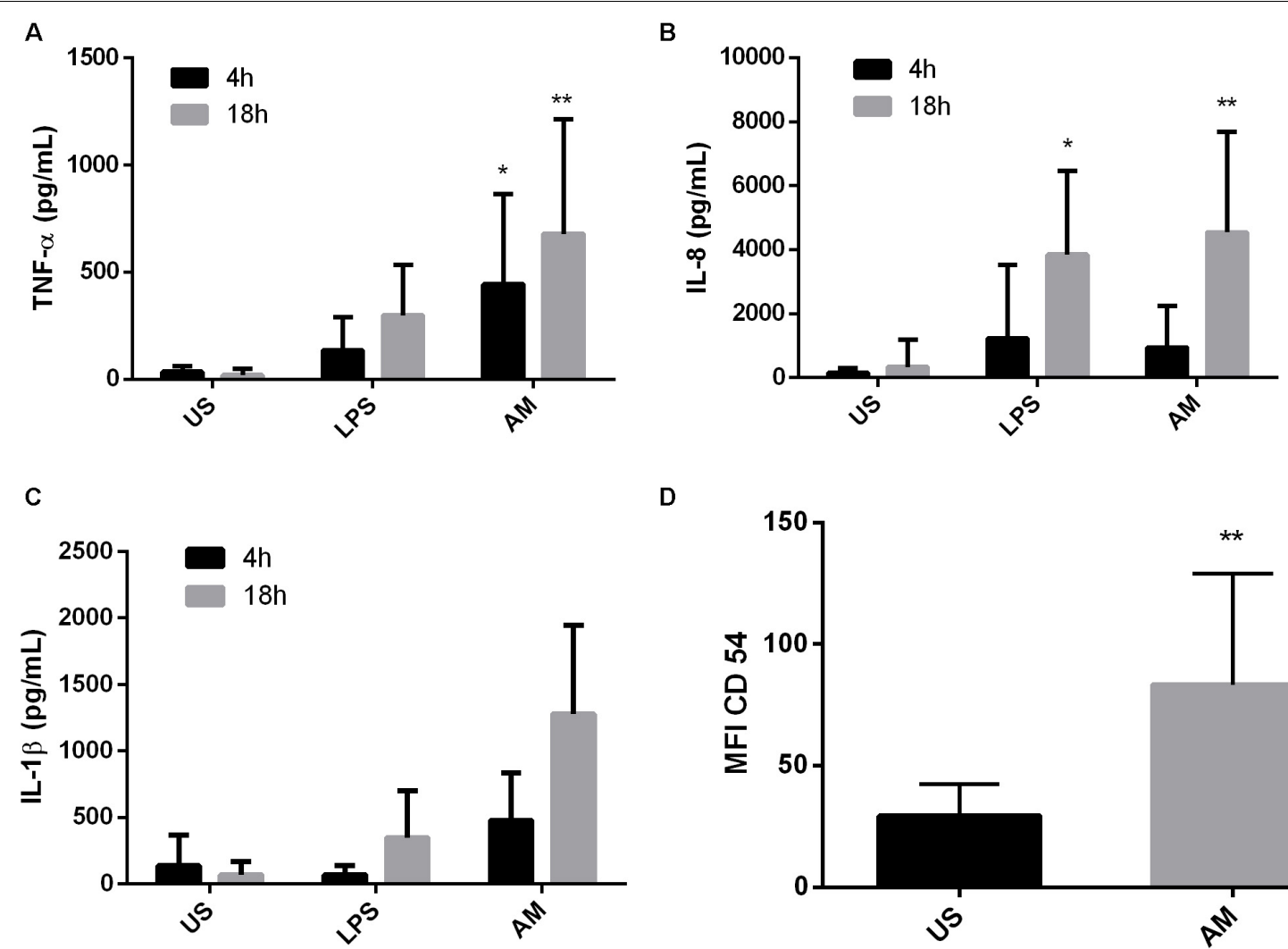

D

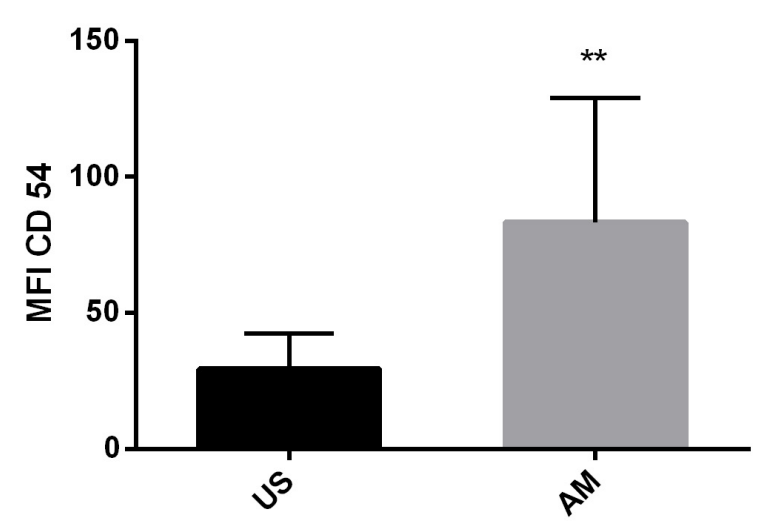

E

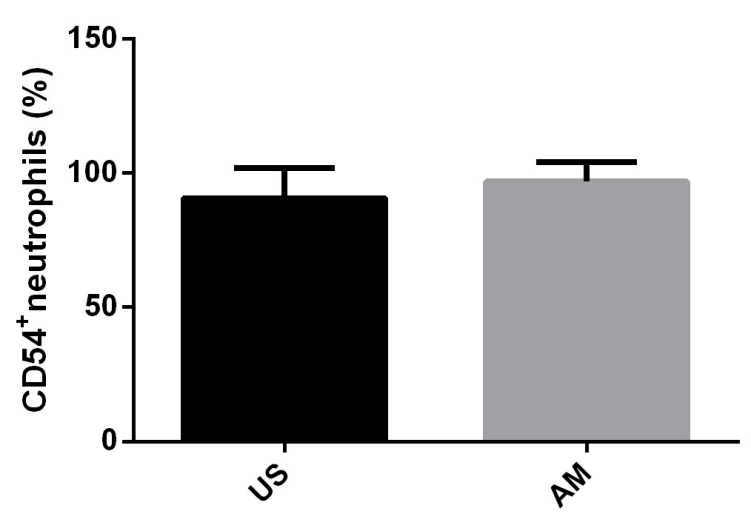

FIGURE 2 | ArtinM induces activation and cytokine production in neutrophils of PCM patients. Neutrophils obtained from the peripheral blood of patients with paracoccidioidomycosis $(n=10)$ were maintained in vitro with the indicated stimuli for 4 and $18 \mathrm{~h}$. Culture supernatants were collected and used for cytokine quantification by ELISA (A: TNF- $\alpha$, B: IL-8, C: IL-1 $\beta$ ). Cell pellets were assayed for CD54 expression (D) and frequency (E) by FACs. AM: ArtinM, US: unstimulated. ${ }^{*} P \leq 0.05,{ }^{* *} P \leq 0.01$ compared to US.

the MFI. As shown in Figure 6A (right bars), ArtinM improved the internalization of dextran particles by neutrophils, which might indicate that the lectin would promote the phagocytosis of not only P. brasiliensis, but also of other microorganisms,.

Because ArtinM promoted the phagocytosis of $\mathrm{Pb} 18$ yeast, we analyzed if the lectin had an effect on the fungicidal capacity of these cells. Indeed, the killing capacity of neutrophils and macrophages was higher when these cells were incubated with ArtinM (Figures 6C,D).

\section{DISCUSSION}

The immunomodulatory protective role played by the ArtinM lectin in murine PCM encouraged us to study the effect of 


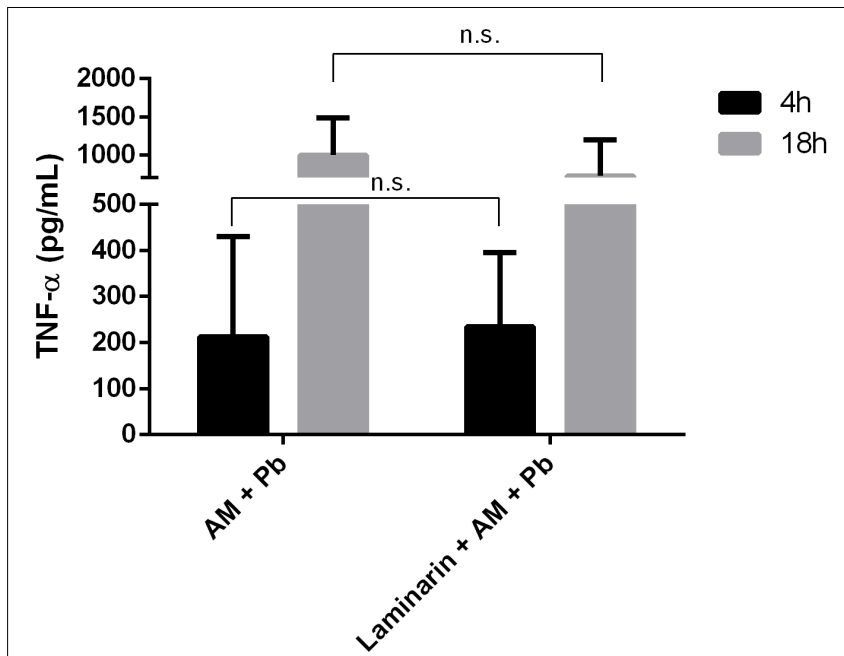

FIGURE 3 | Dectin-1 blockage does not alter TNF- $\alpha$ production induced by ArtinM in infected neutrophils. Neutrophils were obtained from the peripheral blood of healthy individuals $(n=7)$, pre-incubated with laminarin for $30 \mathrm{~min}$, and incubated in vitro with the indicated stimuli, for 4 and $18 \mathrm{~h}$. Culture supernatants were collected and used for TNF- $\alpha$ quantification by ELISA. AM, ArtinM; $\mathrm{Pb}$, P. brasiliensis yeast (yeast:neutrophil ratio of 1:10); ns: non-significant.

this lectin in human leukocytes obtained from healthy control individuals and stimulated in vitro with $P$. brasiliensis yeast, and from PCM patients. One of the most striking features of the immune response in PCM is the immunosuppression of the cellmediated response observed in patients presenting the active form of the disease. In fact, the degree of immunosuppression is associated with the severity of the disease (Musatti et al., 1976; Shikanai-Yasuda et al., 1992; Benard et al., 1997, 2001).

ArtinM stimulates a Th1 immunity conferring resistance to some intracellular pathogens (Ruas et al., 2012; Souza et al., 2013). We reasoned that the study of immune cells during $P$. brasiliensis infection in the presence of immunomodulatory agents such as ArtinM would help to better understand the disease and to develop new treatments. For instance, the analysis of the response of blood cells to therapeutic agents, in terms of cytokine production and expression of activation markers present on the cell surface, provides important information concerning the immunomodulatory activity of those therapeutic agents (Arvå and Andersson, 1999; Collins, 2000; Reddy et al., 2004).

Even with the recent development of less toxic antifungal drugs, fungi still represent the leading cause of death in intensive care units (Shoham and Marwaha, 2010; Paramythiotou et al., 2014). It is known that host defense mechanisms influence the manifestation and severity of fungal diseases (Romani, 2004), and several reports have shown the importance of adjunctive immunotherapies for the treatment of these infections (Kullberg et al., 2014; Cutino-Moguel et al., 2017; Posch et al., 2017). Several plant and pathogen lectins have immunomodulatory properties with potential pharmaceutical applications. The recognition of cell surface receptors by lectins accounts for their immunomodulatory properties; it has been

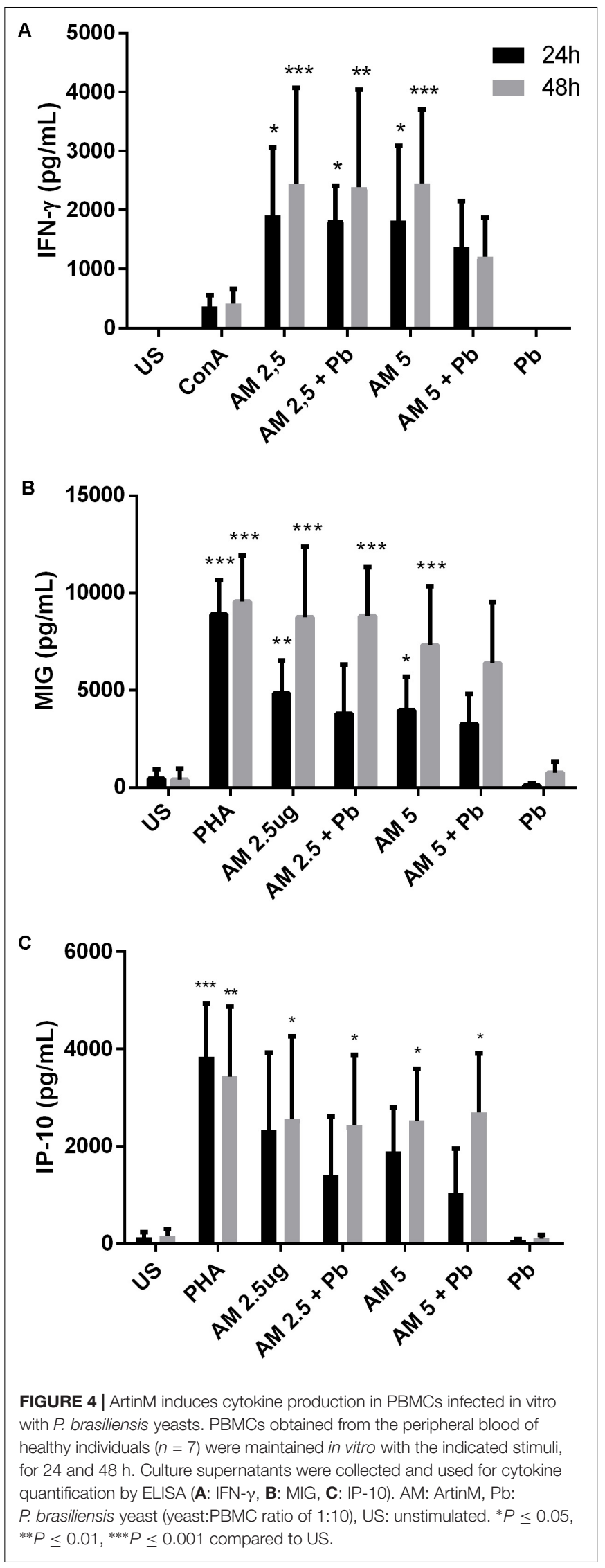

FIGURE 4 | ArtinM induces cytokine production in PBMCs infected in vitro with $P$. brasiliensis yeasts. PBMCs obtained from the peripheral blood of healthy individuals $(n=7)$ were maintained in vitro with the indicated stimuli, quantification by ELISA (A: IFN- $\gamma$, B: MIG, C: IP-10). AM: ArtinM, Pb: ${ }^{* *} P \leq 0.01,{ }^{* * *} P \leq 0.001$ compared to US 


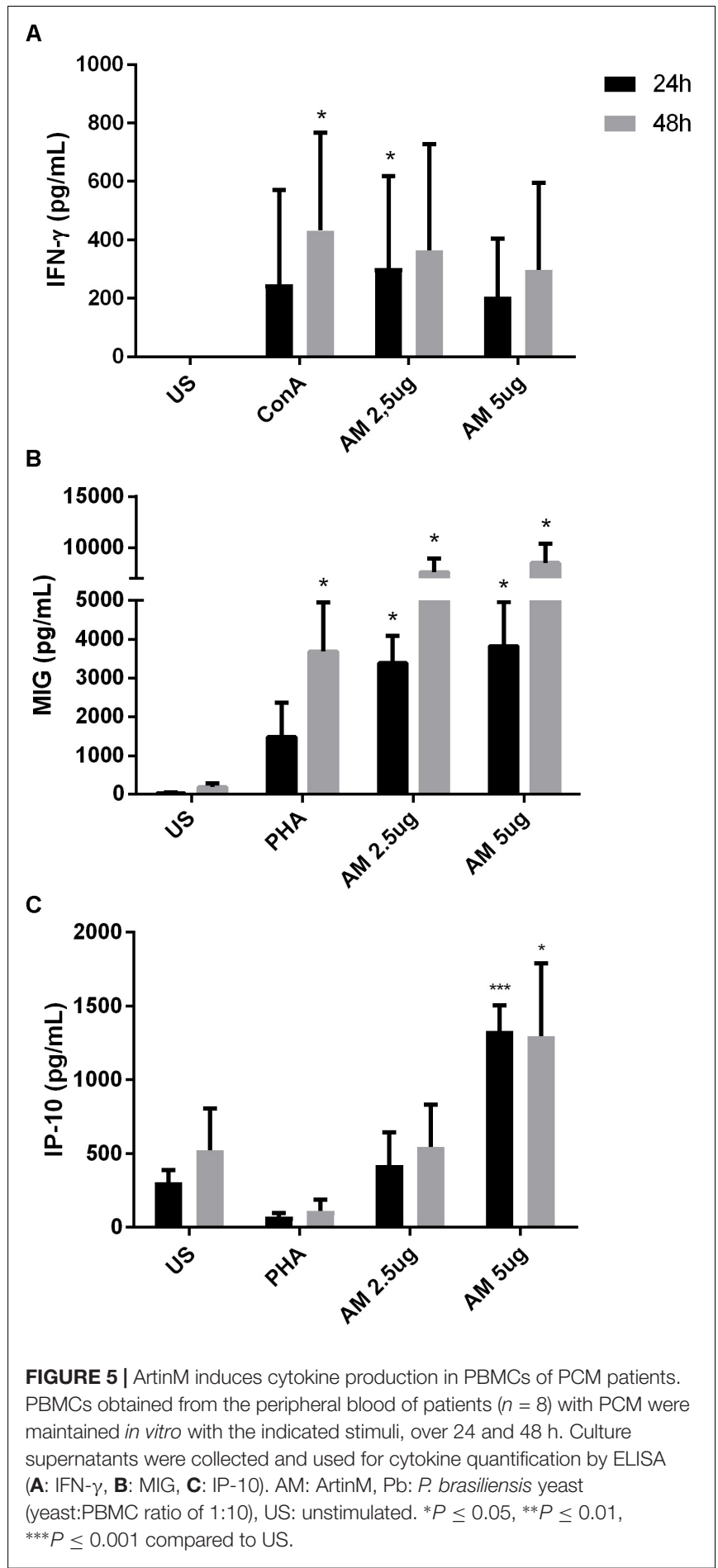

reported that the plant lectin ArtinM acts as a TLR agonist, thereby improving the host immune response (Da Silva and Correia, 2014; Ricci-Azevedo et al., 2017). ArtinM interaction with pattern recognition receptors, such as TLRs, triggers cell signaling events that culminate in the production of IL12 and consequently, Th1 cytokines (Ricci-Azevedo et al., 2017).
TNF- $\alpha$ plays a central role in the host defense against microorganisms as demonstrated by the exacerbation or onset of infectious diseases, such as tuberculosis, that occurs in patients with inflammatory diseases that are treated with antiTNF antibodies (Lin and Ottenhoff, 2008). TNF- $\alpha$ augments the neutrophil oxidative burst in response to a wide range of stimuli, including fungi, bacterial, and protozoan infections (Ferrante, 1992). It has been extensively reported that TNF- $\alpha$ activates both human and murine leukocytes to exert their fungicidal activities against $P$. brasiliensis (Brummer et al., 1989; Gonzales et al., 2003; Rodrigues et al., 2007; Moreira et al., 2008). Loyola et al. (2012) reported an ArtinM-mediated TNF- $\alpha$-induction in murine macrophages. Importantly, TNF- $\alpha$ has chemotactic activity for immune cells, including neutrophils (Ming et al., 1987), thereby contributing to the amplification of the activation of the immune system.

Dectin-1 is a cell surface receptor present in many cells of the immune system, including neutrophils (Taylor et al., 2002). It recognizes $\beta$-glucan, present in the fungal cell wall, and therefore participates in the recognition of many fungal species, including P. brasiliensis (Balderramas et al., 2014; Feriotti et al., 2015; Loures et al., 2015; Bachiega et al., 2016). Recently, Romagnolo et al. (2018) demonstrated that this receptor participates in cytokine secretion by monocytes when stimulated in vitro with $P$. brasiliensis 265 isolate. Our results show that this receptor is not involved in ArtinM activation of neutrophils infected with $\mathrm{Pb} 18$ isolate. We hypothesize that other PRRs might be involved in ArtinM activation of cells during P. brasiliensis infection and this is currently under investigation in our laboratory.

It has been previously demonstrated that the ArtinM lectin activates human neutrophils (Toledo et al., 2009; RicciAzevedo et al., 2016). These activated neutrophils undergo some phenotypic and functional changes such as increased phagocytosis and lysis, L-selectin shedding, and production of inflammatory mediators, such as IL-8 (Toledo et al., 2009). Similarly, our results show that ArtinM induces IL- 8 production in neutrophils from PCM patients, which could increase the anti-apoptotic effect of TNF- $\alpha$ (Cowburn et al., 2004) as well as amplify the immune response. In a recent paper, RicciAzevedo et al. (2016) showed by several methods that ArtinM prolongs the survival of naive neutrophils. In the same report, the authors demonstrated that neutrophils contribute to ArtinMinduced protection against L. major. Specifically, neutrophils infected with the protozoan and stimulated with ArtinM had an enhanced leishmanicidal activity, and produced high levels of TNF- $\alpha$ and IL-1 $\beta$ (Ricci-Azevedo et al., 2016). Likewise, our data show that activation of neutrophils by ArtinM is not inhibited by $P$. brasiliensis infection in vitro, and similar results were obtained with neutrophils from PCM patients.

IL-1 $\beta$ participates in a variety of inflammatory events including production of other cytokines such as IL-6, which contributes to the maintenance of inflammation (Dinarello, 1996). Microbial agents stimulate phagocytic cells to produce IL-1 $\beta$ in its inactive form (pro-IL-1 $\beta$ ). The cleavage of pro-IL$1 \beta$ to its active form, in turn, requires the participation of the inflammasome, a cytosolic multiprotein complex that acts upon recognition of endogenous and pathogenic molecules (Martinon 


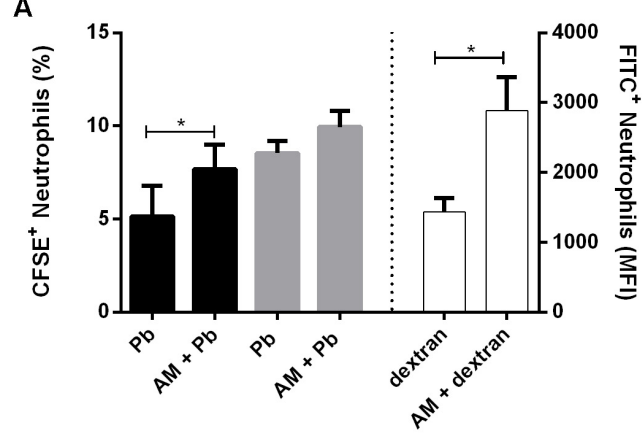

\section{B}
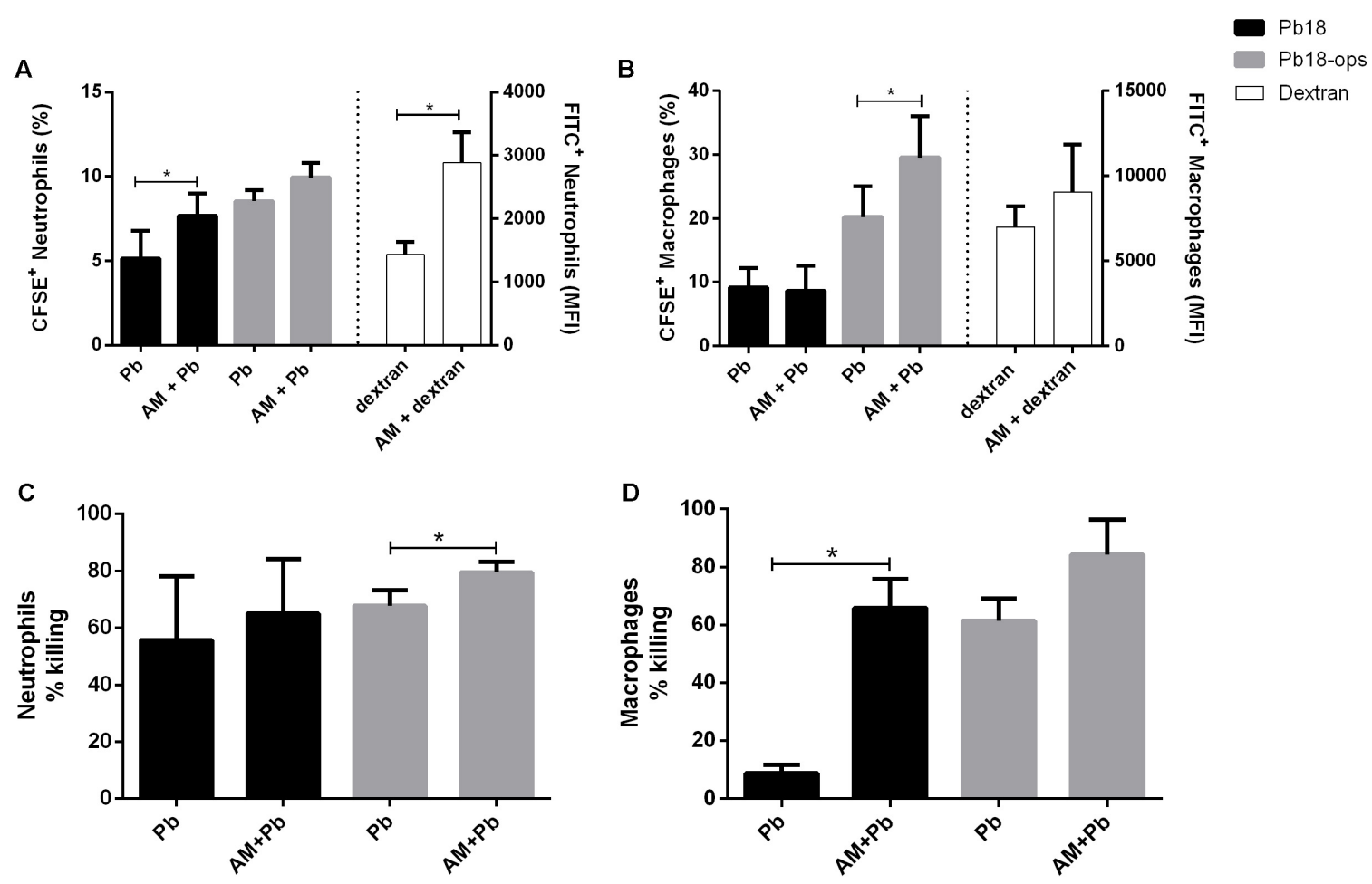

FIGURE 6 | ArtinM promotes increase of $P$. brasiliensis internalization $\mathbf{( A , B )}$ and killing (C,D) by neutrophils and macrophages. Neutrophils and macrophages were maintained in vitro with CFSE-Pb18 yeasts in the presence or not of ArtinM, for $4 \mathrm{~h}$. FlTC-Dextran was used as positive control. (A,B) Cell pellets were assayed for CFSE/FITC frequency and expression by FACs. (C,D) neutrophils and macrophages were lysed, yeast CFU was counted, and the percentage of fungicidal activity was calculated as described in Section "Materials and Methods." AM, ArtinM; Pb, P. brasiliensis yeast. ${ }^{*} P \leq 0.05$, compared to Pb, in the absence of ArtinM.

et al., 2002; Franchi et al., 2010). Importantly, activation of the inflammasome and IL- $1 \beta$ production has been associated with resistance to fungal diseases (Vonk et al., 2006; Gross et al., 2009; Joly et al., 2009). In this regard, Tavares et al. (2013) have shown that murine dendritic cells produce IL-1 $\beta$ via the NLRP3 inflammasome in response to $P$. brasiliensis. In addition, several researchers have reported the important role of inflammasome activation and of the generation of an IL$1 \beta$ inflammatory response during infection with $P$. brasiliensis (Feriotti et al., 2015; Ketelut-Carneiro et al., 2015). Notably, patients with the acute form of PCM present with high serum levels of cytokines of the IL-1 family, including IL-1 $\beta$ (Alves et al., 2018). The increased production of IL-1 $\beta$ in $P$. brasiliensisinfected neutrophils stimulated with ArtinM suggests a possible role of the lectin in inflammasome activation and, hence, in the generation of a protective response against $P$. brasiliensis.

Previously, Loyola et al. (2012) reported that ArtinM promoted an increase in the phagocytosis of $C$. albicans by murine macrophages. ArtinM was also described as a neutrophil activator and, among other functions, induced the phagocytosis of zymosan particles and Listeria monocytogenes (Toledo et al., 2009). Similarly, our results show that ArtinM promotes an increase in the internalization of $P$. brasiliensis yeast by neutrophils and macrophages. However, it has been reported that ingested $P$. brasiliensis can multiply inside macrophages, but this multiplication can be inhibited when the cells are activated (Moscardi-Bacchi et al., 1994). Once we noted that ArtinM activates neutrophils in the presence of $\mathrm{Pb}$ yeast, we also evaluated the fungicidal capacity of these cells stimulated with the lectin. Indeed, ArtinM improved the P. brasiliensis-killing capacity of neutrophils and macrophages in vitro. The increase in phagocytosis promoted by ArtinM may be related to the high production of cytokines, such as TNF- $\alpha$ and IFN- $\gamma$ by these cells when in the presence of the lectin (Figures 1, 2, 4, 5). In fact, several authors have reported the importance of cytokines in the activation of phagocytic cells and killing of $P$. brasiliensis yeast (Cano et al., 1992; Moscardi-Bacchi et al., 1994; Calvi et al., 2003; Carmo et al., 2006; Rodrigues et al., 2007; Acorci-Valério et al., 2010). Similar to ArtinM, a plant lectin, natural components, such as propolis, have been shown to improve the fungicidal activity of macrophages against P. brasiliensis (Murad et al., 2002).

Immunoregulation in PCM is clearly related to the ability of the host to develop a cellular immune response. It has been reported that healthy individuals who live in PCM-endemic areas but do not develop the disease, in spite of being in contact with the fungus, develop a Th1 immune response, with the formation of compact granulomas, leading to the retention and subsequent elimination of the yeasts cells (Mamoni and Blotta, 2005; Benard, 2008). In contrast, in patients with active disease, the cellular Th1 immune response is suppressed, while there is a production of anti-inflammatory and regulatory cytokines, which are associated with fungal evasion and disease 
dissemination (Franco et al., 1987; Benard et al., 2001; Neworal et al., 2003; Mamoni and Blotta, 2006; Ferreira et al., 2010). Our results show that ArtinM activates neutrophils and PBMCs from PCM patients to secrete cytokines and chemokines, which may amplify the immune response against the fungus. In this regard, da Silva et al. (2014) have shown that ArtinM activates murine $\mathrm{CD}^{+} \mathrm{T}$ cells leading to IL-2 production and T-cell proliferation. The authors suggested that ArtinM interaction with $\mathrm{T}$ cells provides an additional mechanism of adaptive Th1-immune response induction by the lectin, thus enhancing the resulting response. Because PCM patients present a downregulated immune response, it is likely that the ArtinM pro-inflammatory stimulus could act as an adjuvant boosting the host immune response.

We found that neutrophils activated by ArtinM have an increased expression of the CD54 protein, a glycoprotein expressed on the cell surface, which functions in neutrophil migration and activation. Previous studies have shown that CD54 expression is upregulated by inflammatory mediators and cytokines such as TNF- $\alpha$ and IL-1 $\beta$ (Wedi et al., 1996; Wang et al., 1997; Roebuck and Finnegan, 1999). Therefore, the production of cytokines by $P$. brasiliensis-infected neutrophils (both in vitro infected and those obtained from PCM patients) stimulated with ArtinM supports the higher expression of CD54 in these cells. Hence, we conclude that ArtinM is able to activate neutrophils during $P$. brasiliensis infection, as demonstrated by an increase in pro-inflammatory cytokines, which is associated with higher CD54 expression. Furthermore, we rule out the involvement of the dectin-1 receptor in ArtinMinduced activation of $P$. brasiliensis-infected neutrophils, because its blockage did not affect TNF- $\alpha$ production or CD54 expression in human neutrophils.

Peripheral blood mononuclear cells are activated during P. brasiliensis infection, and produce Th1 cytokines upon ArtinM stimulation, which supports the lectin immunomodulatory function.

The use of the plant lectin in clinical assays requires additional preliminary studies. The aim of our study was to show that the previously described immunostimulatory properties of ArtinM are replicated in human cells, including those from PCM patients, which are known to be unresponsive to several stimulus (Benard et al., 1997, 2001; Oliveira et al., 2002). It has been recently published that administration in naive mice of low doses of ArtinM $(2.5 \mu \mathrm{g} / \mathrm{mL})$ does not have unwanted effects,

\section{REFERENCES}

Acorci-Valério, M. J., Bordon-Graciani, A. P., Dias-Melicio, L. A., de Assis Golim, M., Nakaira-Takahagi, E., and de Campos Soares, A. M. (2010). Role of TLR2 and TLR4 in human neutrophil functions against Paracoccidioides brasiliensis. Scand. J. Immunol. 71, 99-108. doi: 10.1111/j.1365-3083.2009. 02351.x

Afonso-Cardoso, S. R., Silva, C. V., Ferreira, M. S., and Souza, M. A. (2011). Effect of the Synadenium carinatum latex lectin (ScLL) on Leishmania (Leishmania) amazonensis infection in murine macrophages. Exp. Parasitol. 128, 61-67. doi: 10.1016/j.exppara.2011.02.006

Alves, A. B. R. M., David, M. A., de Castro, L. F., da Silva, R. M., Longhi, L. N. A., Blotta, M. H. S. L., et al. (2018). Differential production of while administration of high doses is only associated with the development of mild inflammatory infiltrates in tissues (Oliveira Brito et al., 2017). This supports the potential use of the lectin as a therapeutic aid. The research on lectins is encouraging thanks to lectin engineering, a promising tool for expanding protein applications and utilities (Hu et al., 2015). Our results support the studies on the use of ArtinM, or ArtinM-like engineered molecules as an adjuvant therapy for PCM, in order to boost the immune response of the patient, or as an alternative to the current therapy.

\section{ETHICS STATEMENT}

The study was approved by the University of Campinas (UNICAMP) Research Ethics Committee (\# 574 507).

\section{AUTHOR CONTRIBUTIONS}

LR: concept and design, data collection, analysis and interpretation of data, in vitro experiments, critical revision, and intellectual content. LG, AJ-J, LOC, LFC: in vitro experiments and data collection. PT: patients' recruitment and clinical evaluation. RM: critical revision. M-CR-B: reagents' supply and critical revision. M-HB: handle funding and supervision, concept and design, analysis and interpretation of data, critical revision, and intellectual content.

\section{FUNDING}

LR, LG, and M-HB received scholarships from Fundação de Amparo à Pesquisa do Estado de São Paulo - São Paulo Research Foundation (Grant Nos. 2013/24742-6, 2014/06155-9, and 2014/12516-4).

\section{ACKNOWLEDGMENTS}

We thank Mrs. Sandra M. O. Thomaz for the purification of the lectin and Rafael Ricci-Azevedo for helpful discussions concerning ArtinM. The funders had no role in study design, data collection, and analysis or preparation of the manuscript.

interleukin-1 family cytokines (IL-1 $\beta$, IL-18, IL-33 and IL-37) in patients with paracoccidioidomycosis: correlation with clinical form and antifungal therapy. Med. Mycol. 56, 332-343. doi: 10.1093/mmy/myx050

Arvå, E., and Andersson, B. (1999). Kinetics of cytokine release and expression of lymphocyte cell-surface activation markers after in vitro stimulation of human peripheral blood mononuclear cells with Streptococcus pneumoniae. Scand. J. Immunol. 49, 237-243. doi: 10.1046/j.1365-3083.1999.00470.x

Bachiega, T. F., Dias-Melicio, L. A., Fernandes, R. K., Balderramas, H. A., Rodrigues, D. R., Ximenes, V. F., et al. (2016). Participation of dectin-1 receptor on NETs release against Paracoccidioides brasiliensis: role on extracellular killing. Immunobiology 221, 228-235. doi: 10.1016/j.imbio.2015.09.003

Bagagli, E., Bosco, S. M., Theodoro, R. C., and Franco, M. (2006). Phylogenetic and evolutionary aspects of Paracoccidioides brasiliensis reveal a long coexistence 
with animal hosts that explain several biological features of the pathogen. Infect. Genet. Evol. 6, 344-351. doi: 10.1016/j.meegid.2005.12.002

Balderramas, H. A., Penitenti, M., Rodrigues, D. R., Bachiega, T. F., Fernandes, R. K., Ikoma, M. R., et al. (2014). Human neutrophils produce IL-12, IL-10, PGE2 and LTB4 in response to Paracoccidioides brasiliensis. Involvement of TLR2, mannose receptor and dectin-1. Cytokine 67, 36-43. doi: 10.1016/j.cyto. 2014.02.004

Barbosa-Lorenzi, V. C., Buranello, P. A., Roque-Barreira, M. C., Jamur, M. C., Oliver, C., and Pereira-da-Silva, G. (2011). The lectin ArtinM binds to mast cells inducing cell activation and mediator release. Biochem. Biophys. Res. Commun. 416, 318-324. doi: 10.1016/j.bbrc.2011.11.033

Barbosa-Lorenzi, V. C., Cecilio, N. T., de Almeida Buranello, P. A., Pranchevicius, M. C., Goldman, M. H., Pereira-da-Silva, G., et al. (2016). Recombinant ArtinM activates mast cells. BMC Immunol. 17:22. doi: 10.1186/s12865-016-0161-0

Bates, D. W., Su, L., Yu, D. T., Chertow, G. M., Seger, D. L., Gomes, D. R., et al. (2001). Correlates of acute renal failure in patients receiving parenteral amphotericin B. Kidney Int. 60, 1452-1459. doi: 10.1046/j.1523-1755.2001. 00948.x

Bellmann, R., and Smuszkiewicz, P. (2017). Pharmacokinetics of antifungal drugs: practical implications for optimized treatment of patients. Infection 45, 737-779. doi: 10.1007/s15010-017-1042-z

Benard, G. (2008). An overview of the immunopathology of human paracoccidioidomycosis. Mycopathologia 165, 209-221. doi: 10.1007/s11046007-9065-0

Benard, G., Mendes-Giannini, M. J., Juvenale, M., Miranda, E. T., and Duarte, A. J. (1997). Immunosuppression in paracoccidioidomycosis: T cell hyporesponsiveness to two Paracoccidioides brasiliensis glycoproteins that elicit strong humoral immune response. J. Infect. Dis. 175, 1263-1267. doi: 10.1086/ 593694

Benard, G., Romano, C. C., Cacere, C. R., Juvenale, M., Mendes-Giannini, M. J., and Duarte, A. J. (2001). Imbalance of IL-2, IFN-gamma and IL-10 secretion in the immunosuppression associated with human paracoccidioidomycosis. Cytokine 13, 248-252. doi: 10.1006/cyto.2000.0824

Borges-Walmsley, M. I., Chen, D., Shu, X., and Walmsley, A. R. (2002). The pathobiology of Paracoccidioides brasiliensis. Trends Microbiol. 10, 80-87. doi: 10.1016/S0966-842X(01)02292-2

Brown, G. D., Herre, J., Williams, D. L., Willment, J. A., Marshall, A. S. J., and Gordon, S. (2003). Dectin-1 mediates the biological effects of $\beta$-glucans. J. Exp. Med. 197, 1119-1124. doi: 10.1084/jem.20021890

Brown, G. D., Taylor, P. R., Reid, D. M., Willment, J. A., Williams, D. L., Martinez-Pomares, L., et al. (2002). Dectin-1 is a major $\beta$-glucan receptor on macrophages. J. Exp. Med. 196, 407-412. doi: 10.1084/jem.20020470

Brummer, E., Castaneda, E., and Restrepo, A. (1993). Paracoccidioidomycosis: an update. Clin. Microbiol. Rev. 6, 89-117. doi: 10.1128/CMR.6.2.89

Brummer, E., Hanson, L. H., Restrepo, A., and Stevens, D. A. (1989). Intracellular multiplication of Paracoccidioides brasiliensis in macrophages: killing and restriction of multiplication by activated macrophages. Infect. Immun. 57, 2289-2294.

Calich, V. L., da Costa, T. A., Felonato, M., Arruda, C., Bernardino, S., Loures, F. V., et al. (2008). Innate immunity to Paracoccidioides brasiliensis infection. Mycopathologia 165, 223-236. doi: 10.1007/s11046-007-9048-1

Calich, V. L., and Kashino, S. S. (1998). Cytokines produced by susceptible and resistant mice in the course of Paracoccidioides brasiliensis infection. Braz. J. Med. Biol. Res. 31, 615-623. doi: 10.1590/S0100-879X1998000500003

Calich, V. L. G., Vaz, C. A. C., and Burger, E. (1998). Immunity to Paracoccidioides brasiliensis infection. Res. Immunol. 149, 407-417. doi: 10.1016/S0923-2494(98) 80764-5

Calvi, S. A., Peracoli, M. T., Mendes, R. P., Marcondes-Machado, J., Fecchio, D., Marques, S. A., et al. (2003). Effect of cytokines on the in vitro fungicidal activity of monocytes from paracoccidioidomycosis patients. Microbes Infect. 5, 107-113. doi: 10.1016/S1286-4579(02)00078-3

Cano, L. E., Arango, R., Salazar, M. E., Brummer, E., Stevens, D. A., and Restrepo, A. (1992). Killing of Paracoccidioides brasiliensis conidia by pulmonary macrophages and the effect of cytokines. J. Med. Vet. Mycol. 30, 161-168. doi: 10.1080/02681219280000211

Cardoso, M. R., Mota, C. M., Ribeiro, D. P., Santiago, F. M., Carvalho, J. V., Araujo, E. C., et al. (2011). ArtinM, a d-mannose-binding lectin from Artocarpus integrifolia, plays a potent adjuvant and immunostimulatory role in immunization against Neospora caninum. Vaccine 29, 9183-9193. doi: 10.1016/ j.vaccine.2011.09.136

Carmo, J. P., Dias-Melicio, L. A., Calvi, S. A., Peraçoli, M. T., and Soares, A. M. (2006). TNF- $\alpha$ activates human monocytes for Paracoccidioides brasiliensis killing by an $\mathrm{H} 2 \mathrm{O} 2$-dependent mechanism. Med. Mycol. 44, 363-368. doi: 10.1080/13693780500536885

Collins, D. P. (2000). Cytokine and cytokine receptor expression as a biological indicator of immune activation: important considerations in the development of in vitro model systems. J. Immunol. Methods 243, 125-145. doi: 10.1016/ S0022-1759(00)00218-0

Coltri, K. C., Oliveira, L. L., Pinzan, C. F., Vendruscolo, P. E., Martinez, R., Goldman, M. H., et al. (2008). Therapeutic administration of KM+ lectin protects mice against Paracoccidioides brasiliensis infection via interleukin-12 production in a toll-like receptor 2-dependent mechanism. Am. J. Pathol. 173, 423-432. doi: 10.2353/ajpath.2008.080126

Coltri, K. C., Oliveira, L. L., Ruas, L. P., Vendruscolo, P. E., Goldman, M. H., Panunto-Castelo, A., et al. (2010). Protection against Paracoccidioides brasiliensis infection conferred by the prophylactic administration of native and recombinant ArtinM. Med. Mycol. 48, 792-799. doi: 10.3109/13693780903501671

Cowburn, A. S., Deighton, J., Walmsley, S. R., and Chilvers, E. R. (2004). The survival effect of TNF- $\alpha$ in human neutrophils is mediated via NF-кBdependent IL-8 release. Eur. J. Immunol. 34, 1733-1743. doi: 10.1002/eji. 200425091

Custodio, L. A., Loyola, W., Conchon-Costa, I., da Silva Quirino, G. F., and Felipe, I. (2011). Protective effect of Artin M from extract of Artocarpus integrifolia seeds by Th1 and Th17 immune response on the course of infection by Candida albicans. Int. Immunopharmacol. 11, 1510-1515. doi: 10.1016/j. intimp.2011.05.005

Cutino-Moguel, M. T., Eades, C., Rezvani, K., and Armstrong-James, D. (2017). Immunotherapy for infectious diseases in haematological immunocompromise. Br. J. Haematol 177, 348-356. doi: 10.1111/bjh.14595

Da Silva, L. C. N., and Correia, M. T. S. (2014). Plant lectins and Toll-like receptors: implications for therapy of microbial infections. Front. Microbiol. 5:20. doi: $10.3389 /$ fmicb. 2014.00020

da Silva, T. A., Souza, M. A., Cecílio, N. T., and Roque-Barreira, M. C. (2014). Activation of spleen cells by ArtinM may account for its immunomodulatory properties. Cell Tissue Res. 357, 719-730. doi: 10.1007/s00441-014-1879-8

da Silva Correia, J., and Ulevitch, R. J. (2002). MD-2 and TLR4 N-linked glycosylations are important for a functional lipopolysaccharide receptor. J. Biol. Chem. 277, 1845-1854. doi: 10.1074/jbc.M109910200

de Oliveira, P. S., Rêgo, M. J., da Silva, R. R., Cavalcanti, M. B., Galdino, S. L., Correia, M. T., et al. (2013). Cratylia mollis 1, 4 lectin: a new biotechnological tool in IL-6, IL-17A, IL-22, and IL-23 induction and generation of immunological memory. Biomed Res. Int. 2013:263968. doi: $10.1155 / 2013 / 263968$

Dinarello, C. (1996). Biologic basis for interleukin-1 in disease. Blood 87, 2095-2147.

Farber, J. M. (1990). A macrophage mRNA selectively induced by gammainterferon encodes a member of the platelet factor 4 family of cytokines. Proc. Natl. Acad. Sci. U.S.A. 87, 5238-5242. doi: 10.1073/pnas.87.14.5238

Feriotti, C., Bazan, S. B., Loures, F. V., Araujo, E. F., Costa, T. A., and Calich, V. L. (2015). Expression of dectin-1 and enhanced activation of NALP3 inflammasome are associated with resistance to paracoccidioidomycosis. Front. Microbiol. 6:913. doi: 10.3389/fmicb.2015.00913

Ferrante, A. (1992). Activation of neutrophils by interleukins-1 and -2 and tumor necrosis factors. Immunol. Ser. 57, 417-436.

Ferreira, M. C., de Oliveira, R. T., da Silva, R. M., Blotta, M. H., and Mamoni, R. L. (2010). Involvement of regulatory $\mathrm{T}$ cells in the immunosuppression characteristic of patients with paracoccidioidomycosis. Infect. Immun. 78, 4392-4401. doi: 10.1128/IAI.00487-10

Franchi, L., Muñoz-Planillo, R., Reimer, T., Eigenbrod, T., and Núñez, G. (2010). Inflammasomes as microbial sensors. Eur. J. Immunol. 40, 611-615. doi: $10.1002 /$ eji. 200940180

Franco, M., Montenegro, M. R., Mendes, R. P., Marques, S. A., Dillon, N. L., and Mota, N. G. S. (1987). Paracoccidioidomycosis: a recently proposed classification of its clinical forms. Rev. Soc. Bras. Med. Trop. 20, 129-132. doi: $10.1590 /$ S0037-86821987000200012 
Gonzales, A., Sahaza, J. H., Ortiz, B. L., Restrepo, A., and Cano, L. E. (2003). Production of pro-inflammatory cytokines during the early stages of experimental Paracoccidioides brasiliensis infection. Med. Mycol. 41, 391-399. doi: 10.1080/13693780310001610038

Gross, O., Poeck, H., Bscheider, M., Dostert, C., Hannesschlager, N., Endres, S., et al. (2009). Syk kinase signalling couples to the Nlrp3 inflammasome for anti-fungal host defence. Nature 459, 433-436. doi: 10.1038/nature07965

Hu, D., Tateno, H., and Hirabayashi, J. (2015). Lectin engineering, a molecular evolutionary approach to expanding the lectin utilities. Molecules 20, 7637-7656. doi: 10.3390/molecules20057637

Joly, S., Ma, N., Sadler, J. J., Soll, D. R., Cassel, S. L., and Sutterwala, F. S. (2009). Cutting edge: Candida albicans hyphae formation triggers activation of the Nlrp3 inflammasome. J. Immunol. 183, 3578-3581. doi: 10.4049/jimmunol. 0901323

Kashino, S. S., Calich, V. L., Burger, E., and Singer-Vermes, L. M. (1985). In vivo and in vitro characteristics of six Paracoccidioides brasiliensis strains. Mycopathologia 92, 173-178. doi: 10.1007/BF00437630

Ketelut-Carneiro, N., Silva, G. K., Rocha, F. A., Milanezi, C. M., Cavalcanti-Neto, F. F., Zamboni, D. S., et al. (2015). IL-18 triggered by the Nlrp3 inflammasome induces host innate resistance in a pulmonary model of fungal infection. J. Immunol. 194, 4507-4517. doi: 10.4049/jimmunol.1402321

Kullberg, B.-J., van de Veerdonk, F., and Netea, M. G. (2014). Immunotherapy: a potential adjunctive treatment for fungal infection. Curr. Opin. Infect. Dis. 27, 511-516. doi: 10.1097/qco.0000000000000105

Lin, M. Y., and Ottenhoff, T. H. (2008). Not to wake a sleeping giant: new insights into host-pathogen interactions identify new targets for vaccination against latent Mycobacterium tuberculosis infection. Biol. Chem. 389, 497-511. doi: 10.1515/BC.2008.057

Loures, F. V., Araujo, E. F., Feriotti, C., Bazan, S. B., and Calich, V. L. (2015). TLR4 cooperates with dectin- 1 and mannose receptor to expand Th17 and Tc17 cells Induced by Paracoccidioides brasiliensis stimulated dendritic cells. Front. Microbiol. 6:261. doi: 10.3389/fmicb.2015.00261

Loyola, A. M., Custodio, L. A., Felipe, I., Conchon-Costa, I., Carvalho, P. G., Quirino, G. F., et al. (2012). Artin M enhances TNF- $\alpha$ production and phagocytosis of Candida albicans mediated by dectin-1 and mannose receptors. Int. Immunopharmacol. 12, 378-383. doi: 10.1016/j.intimp.2011.12.010

Luster, A. D., Unkeless, J. C., and Ravetch, J. V. (1985). Gamma-interferon transcriptionally regulates an early-response gene containing homology to platelet proteins. Nature 315, 672-676. doi: 10.1038/315672a0

Mamoni, R. L., and Blotta, M. H. (2005). Kinetics of cytokines and chemokines gene expression distinguishes Paracoccidioides brasiliensis infection from disease. Cytokine 32, 20-29. doi: 10.1016/j.cyto.2005.07.006

Mamoni, R. L., and Blotta, M. H. (2006). Flow-cytometric analysis of cytokine production in human paracoccidioidomycosis. Cytokine 35, 207-216. doi: 10.1016/j.cyto.2006.08.005

Mariano, V. S., Zorzetto-Fernandes, A. L., da Silva, T. A., Ruas, L. P., Nohara, L. L., Almedia, I. C., et al. (2014). Recognition of TLR2 N-glycans: critical role in ArtinM immunomodulatory activity. PLoS One 9:e98512. doi: 10.1371/journal. pone.0098512

Marques, S. A. (2003). Paracoccidioidomicose: atualização epidemiológica, clínica e terapêutica. An. Bras. Dermatol. 78, 135-146. doi: 10.1590/S036505962003000200002

Marques, S. A. (2012). Paracoccidioidomycosis. Clin. Dermatol. 30, 610-615. doi: 10.1016/j.clindermatol.2012.01.006

Martinez, R. (2010). Paracoccidioidomycosis: the dimension of the problem of a neglected disease. Rev. Soc. Bras. Med. Trop. 43:480. doi: 10.1590/S003786822010000400034

Martinon, F., Burns, K., and Tschopp, J. (2002). The inflammasome: a molecular platform triggering activation of inflammatory caspases and processing of proIL- $\beta$. Mol. Cell 10, 417-426. doi: 10.1016/S1097-2765(02)00599-3

Ming, W. J., Bersani, L., and Mantovani, A. (1987). Tumor necrosis factor is chemotactic for monocytes and polymorphonuclear leukocytes. J. Immunol. 138, 1469-1474.

Moreira, A. P., Dias-Melício, L. A., Peraçoli, M. T., Calvi, S. A., and Victoriano de Campos Soares, A. M. (2008). Killing of Paracoccidioides brasiliensis yeast cells by IFN-gamma and TNF-alpha activated murine peritoneal macrophages: evidence of $\mathrm{H}_{2} \mathrm{O}_{2}$ and NO effector mechanisms. Mycopathologia 166, 17-23. doi: $10.1007 / \mathrm{s} 11046-007-9046-3$
Moreno, A. N., Jamur, M. C., Oliver, C., and Roque-Barreira, M. C. (2003). Mast cell degranulation induced by lectins: effect on neutrophil recruitment. Int. Arch. Allergy Immunol. 132, 221-230. doi: 10.1159/000074303

Moscardi-Bacchi, M., Brummer, E., and Stevens, D. A. (1994). Support of Paracoccidioides brasiliensis multiplication by human monocyte or macrophages: inhibition by activated phagocytes. J. Med. Microbiol. 40, 159-164. doi: 10.1099/00222615-40-3-159

Murad, J. M., Calvi, S. A., Soares, A. M., Bankova, V., and Sforcin, J. M. (2002). Effects of propolis from Brazil and Bulgaria on fungicidal activity of macrophages against Paracoccidioides brasiliensis. J. Ethnopharmacol. 79, 331-334. doi: 10.1016/S0378-8741(01)00404-4

Musatti, C. C., Rezkallah, M. T., Mendes, E., and Mendes, N. F. (1976). In vivo and in vitro evaluation of cell-mediated immunity in patients with paracoccidiodomycosis. Cell. Immunol. 24, 365-378. doi: 10.1016/00088749(76)90220-3

Nett, J. E., and Andes, D. R. (2016). Antifungal agents. Infect. Dis. Clin. North Am. 30, 51-83. doi: 10.1016/j.idc.2015.10.012

Neworal, E. P., Altemani, A., Mamoni, R. L., Noronha, I. L., and Blotta, M. H. (2003). Immunocytochemical localization of cytokines and inducible nitric oxide synthase (iNOS) in oral mucosa and lymph nodes of patients with paracoccidioidomycosis. Cytokine 21, 234-241. doi: 10.1016/S1043-4666(03) 00051-6

Oliveira, S. J., Mamoni, R. L., Musatti, C. C., Papaiordanou, P. M., and Blotta, M. H. (2002). Cytokines and lymphocyte proliferation in juvenile and adult forms of paracoccidioidomycosis: comparison with infected and non-infected controls. Microbes Infect. 4, 139-144. doi: 10.1016/S1286-4579(01)01521-0

Oliveira Brito, P. K. M., Gonçalves, T. E., Fernandes, F. F., Miguel, C. B., Rodrigues, W. F., Lazo Chica, J. E., et al. (2017). Systemic effects in naïve mice injected with immunomodulatory lectin ArtinM. PLoS One 12:e0187151. doi: 10.1371/ journal.pone.0187151

Panunto-Castelo, A., Souza, M. A., Roque-Barreira, M. C., and Silva, J. S. (2001). $\mathrm{KM}(+)$, a lectin from Artocarpus integrifolia, induces IL-12 40 production by macrophages and switches from type 2 to type 1 cell-mediated immunity against Leishmania major antigens, resulting in $\mathrm{BALB} / \mathrm{c}$ mice resistance to infection. Glycobiology 11, 1035-1042. doi: 10.1093/glycob/11.12.1035

Paramythiotou, E., Frantzeskaki, F., Flevari, A., Armaganidis, A., and Dimopoulos, G. (2014). Invasive fungal infections in the ICU: how to approach, how to treat. Molecules 19, 1085-1119. doi: 10.3390/molecules19011085

Pereira-da-Silva, G., Moreno, A. N., Marques, F., Oliver, C., Célia Jamur, M., Panunto-Castelo, A., et al. (2006). Neutrophil activation induced by the lectin KM+ involves binding to CXCR2. Biochim. Biophys. Acta 1760, 86-94. doi: 10.1016/j.bbagen.2005.09.011

Poiroux, G., Barre, A., van Damme, E. J. M., Benoist, H., and Rouge, P. (2017). Plant lectins targeting O-glycans at the cell surface as tools for cancer diagnosis, prognosis and therapy. Int. J. Mol. Sci. 18:1232. doi: 10.3390/ijms18061232

Posch, W., Steger, M., Wilflingseder, D., and Lass-Florl, C. (2017). Promising immunotherapy against fungal diseases. Expert Opin. Biol. Ther. 17, 861-870. doi: 10.1080/14712598.2017.1322576

Reddy, M., Eirikis, E., Davis, C., Davis, H. M., and Prabhakar, U. (2004). Comparative analysis of lymphocyte activation marker expression and cytokine secretion profile in stimulated human peripheral blood mononuclear cell cultures: an in vitro model to monitor cellular immune function. J. Immunol. Methods 293, 127-142. doi: 10.1016/j.jim.2004.07.006

Reis, E. A., Athanazio, D. A., Cavada, B. S., Teixeira, E. H., de Paulo Teixeira Pinto, V., Carmo, T. M., et al. (2008). Potential immunomodulatory effects of plant lectins in Schistosoma mansoni infection. Acta Trop. 108, 160-165. doi: 10.1016/j.actatropica.2008.05.025

Restrepo, A., Gómez, B. L., and Tobón, A. (2012). Paracoccidioidomycosis: Latin America's own fungal disorder. Curr. Fungal Infect. Rep. 6, 303-311. doi: 10.1007/s12281-012-0114-x

Ricci-Azevedo, R., Oliveira, A. F., Conrado, M. C., Carvalho, F. C., and Roque-Barreira, M. C. (2016). Neutrophils contribute to the protection conferred by ArtinM against intracellular pathogens: a study on Leishmania major. PLoS Negl. Trop. Dis. 10:e0004609. doi: 10.1371/journal.pntd. 0004609

Ricci-Azevedo, R., Roque-Barreira, M.-C., and Gay, N. J. (2017). Targeting and recognition of toll-like receptors by plant and pathogen lectins. Front. Immunol. 8:1820. doi: 10.3389/fimmu.2017.01820 
Rodrigues, D. R., Dias-Melício, L. A., Calvi, S. A., Peraçoli, M. T., and Soares, A. M. (2007). Paracoccidioides brasiliensis killing by IFN- $\gamma$, TNF- $\alpha$ and GMCSF activated human neutrophils: role for oxygen metabolites. Med. Mycol. 45, 27-33. doi: 10.1080/13693780600981676

Roebuck, K. A., and Finnegan, A. (1999). Regulation of intercellular adhesion molecule-1 (CD54) gene expression. J. Leukoc. Biol. 66, 876-888. doi: 10.1002/ jlb.66.6.876

Romagnolo, A. G., de Quaglia, E., Silva, J. C., Della Coletta, A. M., Gardizani, T. P., Martins, A. T. L., et al. (2018). Role of Dectin-1 receptor on cytokine production by human monocytes challenged with Paracoccidioides brasiliensis. Mycoses 61, 222-230. doi: 10.1111/myc. 12725

Romani, L. (2004). Immunity to fungal infections. Nat. Rev. Immunol. 4, 1-23. doi: $10.1038 /$ nri1255

Romani, L. (2011). Immunity to fungal infections. Nat. Rev. Immunol. 11, 275-288. doi: $10.1038 /$ nri2939

Ruas, L. P., Carvalho, F. C., and Roque-Barreira, M. C. (2012). ArtinM offers new perspectives in the development of antifungal therapy. Front. Microbiol. 3:218. doi: $10.3389 /$ fmicb. 2012.00218

Santos-de-Oliveira, R., Dias-Baruffi, M., Thomaz, S. M., Beltamini, L. M., and Roque-Barreira, M. C. (1994). A neutrophil migration-inducing lectin from Artocarpus integrifolia. J. Immunol. 153, 1798-1807.

Sharon, N. (2008). Lectins: past, present and future. Biochem. Soc. Trans. 36, 1457-1460. doi: 10.1042/BST0361457

Sharon, N., and Lis, H. (2004). History of lectins: from hemagglutinins to biological recognition molecules. Glycobiology 14, 53R-62R. doi: 10.1093/glycob/cwh122

Shikanai-Yasuda, M. A., Higaki, Y., Uip, D. E., Mori, N. S., Del Negro, G., Melo, N. T., et al. (1992). Bone marrow involvement and eosinophilia in paracoccidioidomycosis. Rev. Inst. Med. Trop. São Paulo 34, 85-90. doi: 10.1590/S0036-46651992000200002

Shoham, S., and Marwaha, S. (2010). Invasive fungal infections in the ICU. J. Intensive Care Med. 25, 78-92. doi: 10.1177/0885066609355262

Souza, M. A., Carvalho, F. C., Ruas, L. P., Ricci-Azevedo, R., and Roque-Barreira, M. C. (2013). The immunomodulatory effect of plant lectins: a review with emphasis on ArtinM properties. Glycoconj. J. 30, 641-657. doi: 10.1007/s10719012-9464-4

Tavares, A. H., Magalhães, K. G., Almeida, R. D., Correa, R., Burgel, P. H., and Bocca, A. L. (2013). NLRP3 inflammasome activation by Paracoccidioides brasiliensis. PLoS Negl. Trop. Dis. 7:e2595. doi: 10.1371/journal.pntd.0002595

Taylor, P. R., Brown, G. D., Reid, D. M., Willment, J. A., Martinez-Pomares, L., Gordon, S., et al. (2002). The $\beta$-glucan receptor, dectin-1, is predominantly expressed on the surface of cells of the monocyte/macrophage and neutrophil lineages. J. Immunol. 169, 3876-3882. doi: 10.4049/jimmunol.169.7.3876

Teixeira, C. R., Cavassani, K. A., Gomes, R. B., Teixeira, M. J., Roque-Barreira, M. C., Cavada, B. S., et al. (2006). Potential of KM+ lectin in immunization against Leishmania amazonensis infection. Vaccine 24, 3001-3008. doi: 10.1016/ j.vaccine.2005.11.067

Teixeira, M. M., Theodoro, R. C., de Carvalho, M. J., Fernandes, L., Paes, H. C., Hahn, R. C., et al. (2009). Phylogenetic analysis reveals a high level of speciation in the Paracoccidioides genus. Mol. Phylogenet. Evol. 52, 273-283. doi: 10.1016/ j.ympev.2009.04.005

Teixeira Mde, M., Theodoro, R. C., Oliveira, F. F., Machado, G. C., Hahn, R. C., Bagagli, E., et al. (2014). Paracoccidioides lutzii sp. nov.: biological and clinical implications. Med. Mycol. 52, 19-28. doi: 10.3109/13693786.2013. 794311

Toledo, K. A., Scwartz, C., Oliveira, A. F., Conrado, M. C., Bernardes, E. S., Fernandes, L. C., et al. (2009). Neutrophil activation induced by ArtinM: release of inflammatory mediators and enhancement of effector functions. Immunol. Lett. 123, 14-20. doi: 10.1016/j.imlet.2009.01.009

Unitt, J., and Hornigold, D. (2011). Plant lectins are novel Toll-like receptor agonists. Biochem. Pharmacol. 81, 1324-1328. doi: 10.1016/j.bcp.2011.03.010

Vonk, A. G., Netea, M. G., van Krieken, J. H., Iwakura, Y., van der Meer, J. W. M., and Kullberg, B. J. (2006). Endogenous interleukin (IL)- $1 \alpha$ and IL-1 $\beta$ are crucial for host defense against disseminated candidiasis. J. Infect. Dis. 193, 1419-1426. doi: $10.1086 / 503363$

Wang, J. H., Sexton, D. M., Redmond, H. P., Watson, R. W., Croke, D. T., and Bouchier-Hayes, D. (1997). Intercellular adhesion molecule-1 (ICAM-1) is expressed on human neutrophils and is essential for neutrophil adherence and aggregation. Shock 8, 357-361. doi: 10.1097/00024382-19971100000007

Wedi, B., Elsner, J., Czech, W., Butterfield, J. H., and Kapp, A. (1996). Modulation of intercellular adhesion molecule 1 (ICAM-1) expression on the human mast-cell line (HMC)-1 by inflammatory mediators. Allergy 51, 676-684. doi: 10.1111/j.1398-9995.1996.tb04447.x

Conflict of Interest Statement: The authors declare that the research was conducted in the absence of any commercial or financial relationships that could be construed as a potential conflict of interest.

The handling Editor declared a shared affiliation, though no other collaboration, with one of the authors M-CR-B.

Copyright (c) 2018 Ruas, Genaro, Justo-Junior, Coser, de Castro, Trabasso, Mamoni, Roque-Barreira and Blotta. This is an open-access article distributed under the terms of the Creative Commons Attribution License (CC BY). The use, distribution or reproduction in other forums is permitted, provided the original author(s) and the copyright owner are credited and that the original publication in this journal is cited, in accordance with accepted academic practice. No use, distribution or reproduction is permitted which does not comply with these terms. 